\title{
INCIDENCE OF INTRACRANIAL COMPLICATIONS OF CHRONIC SUPPURATIVE OTITIS MEDIA
}

\author{
AKAIDUZZAMAN DGM ${ }^{1}$, FAKIR MAY ${ }^{2}$, ALAM ABMK ${ }^{3}$, TALUKDER DC ${ }^{4}$
}

\begin{abstract}
:
This is a study of patients having Chronic suppurative otitis media (CSOM) admitted in Bangabandhu Sheikh Mujib Medical University (formerly IPGM\&R), Dhaka Medical College Hospital \& Mitford Hospital in the last 20 years (from July, 1990 to June, 2010). Patients diagnosed as having intracranial complication (ICC) due to CSOM were included in the study. Out of 5197 patients admitted in ENT department in the last 20 years, 633 (8.2\%) patients developed intracranial complications; 379 patients between July, 1990 and June, 2000 (groupI) and 254 patients between July, 2000 and June, 2010 (group-II) demonstrating a decline of about 33\%. $Z$ value $=2.24$ corresponds to $p<0.05$ (significant). Thus the ICC has decreased significantly in group II in comparison to group-I. Out of 3126 patients with attico-antral disease 627 patients developed ICC and out of 2071 patients with tubotympanic disease 6 patients developed ICC. It shows that atticoantral disease is mostly causing the ICC. A male preponderance was found in both groups. Out of 633 patients 409 was male and 224 was female whose age ranged from 5-54 years. The most common age group involved is 11-20 years with a mean age of 20.6 years. Common intracranial complications found were meningitis 256 (40\%), Brain abscess 237 (37.5\%), extradural abscess 114 (18\%), followed by a few of lateral sinus thrombosis 18 (3\%), Subdural abscess 6 (1\%) and otitic hydrocephalus 2(.31\%). Multiple complications were present in about 152 (24\%) of the patients. Combined intra and extracranial complication was present in 139 (22\%) cases. Patients having CSOM with ICC have morbidity of $16 \%$ and mortality of $17 \%$, mortality was mostly due to brain abscess. Morbidity in group II is reduced but not significantly different from that in group-I. Mortality in patients with ICC in group-II is increased to some extent but not significantly different from that in group-I. Most common symptoms of patients with ICC on admission were fever, headache, hearing loss, otalgia, foul smelling discharge, vestibular symptoms and lethargy. The most observed otoscopic findings were purulent discharge/perforation in 95\%, cholesteatoma 80\%, granulation tissue/ polyp 21\%.
\end{abstract}

Key words: Chronic suppurative otitis media, Intracranial complication.

J Dhaka Med Coll. 2012; 21(1) : 76-82.

\section{Introduction:}

Chronic suppurative otitis media (CSOM), defined as a chronic inflammation of the middle ear \& mastoid cavity, which presents with recurrent ear discharges through a tympanic perforation ${ }^{1}$. The disease usually begins in childhood (first 6 years of child's life, with a peak around 2 years) as a spontaneous tympanic perforation due to an acute infection of the middle ear, known as acute otitis media $(\mathrm{AOM})^{1,2}$. Prevalence surveys show that the global burden of illness from CSOM involves 65330 million individuals with draining ears. CSOM accounts for 28000 deaths in 1990.
Western pacific \& Southeast Asian regions would contribute about $85-90 \%$ of the global burden from CSOM, with India \& china accounting for much of the burden, the former by its high CSOM prevalence rate and the latter by its sheer size. Rates of $1-2 \%$ were considered low and 3-6\% was high. Indian prevalence of $7.8 \%$ is high ${ }^{1}$. Incidence of CSOM in Bangladesh has been declining for the last few years. In 1977 it was $15.06 \%{ }^{16} \&$ in 2002 it was $6 \% 3$. Otitis media is a potentially serious disease chiefly because of its complications, which may threaten life and health. Complications of otitis media (cranial and

1. Dr. D.G.M. Akaiduzzaman, Assistant Professor of ENT, Sir Salimullah Medical College, Dhaka.

2. Dr. Md. Abu Yusuf Fakir, Assistant Professor of ENT, Dhaka Medical College, Dhaka.

3. Dr. A.B.M. Khorshed Alam, Assistant Professor of ENT, Dhaka Medical College, Dhaka.

4. Dr. Debesh Chandra Talukder, Assistant Professor of ENT, Dhaka Medical College, Dhaka

Correspondence: Dr. D.G.M. Akaiduzzaman, Assistant Professor of ENT, Sir Salimullah Medical College, Dhaka. 
extracranial) can occur in individuals of any age, but they occur much more commonly in children in the first two decades of life. The dominant cranial complication is postauricular abscess, and the dominant intracranial complication is meningitis. Chronic otitis media can lead to intracranial complications, which were more common in pre-antibiotic era as compared to the present antibiotic era ${ }^{2}$. CSOM with its complications including the intracranial complication (ICC) is a common otolaryngologic problem in Bangladesh ${ }^{4}$. Its high incidence in low socioeconomic status is associated with poor hygiene, overcrowding associated with ignorance and lack of awareness of disease and its consequences amongst patients ${ }^{5}$. In developed countries the incidence of intracranial complication (ICC) has come down to $0.04 \%$ of all cases of $\mathrm{CSOM}^{6}$. Population based estimates in developing countries range from $24 \%$ in Thailand to $1.8 \%$ in Africa ${ }^{1}$. In a rural area of India it was found to be $4.26 \%{ }^{7}$. The aim of this study was to investigate the possible changes in frequency and type of intracranial complication (ICC) including the morbidity and mortality of patients with CSOM and intracranial complication (ICC) admitted in ENT department of Bangabandhu Sheikh Mujib Medical University (BSMMU), Dhaka Medical College Hospital \& Mitford Hospital, Dhaka.

\section{Materials \& Methods:}

Bangabandhu Sheikh Mujib Medical University (BSMMU), formerly known as IPGM\&R, Dhaka Medical College Hospital and Mitford Hospital are three referral hospital in the country and the patients admitted in ENT department remained fairly constant since 1990's. Indoor department of these hospitals are offering surgical treatment of chronic suppurative otitis media (CSOM). Medical charts of all patients who had been referred for surgical treatment for CSOM (5197 patients) were reviewed and the charts of the patients with CSOM and its sequelae between July, 1990 and June, 2010 were assessed. Patients diagnosed as having intracranial complication (ICC) due to CSOM were included in the study. Records of all these patients were reviewed regarding age, sex, initial symptoms, otoscopic with microscopic findings, operative findings, types of complications by neurological examination with CT scan in case of suspected ICC, treatment, hospital course and short term outcome at discharge. During surgery the extent of the disease, the status of the dural plate, sinus plate, fallopian canal and the status of the ossicles were evaluated. The patients were divided into two groups, those operated on or treated between July 1990 and June 2000 (group-I) and July 2000 and June 2010 (groupII). The two groups were compared with regard to age, sex, otoscopic findings and rate of complications in comparison to number of CSOM. After compiling result the significance of this study was tested statistically by $Z$ test.

\section{Results:}

Out of 5197 patients admitted in ENT department in the last 20 years, 633 (8.2\%) patients developed intracranial complications. 379 patients were between July 1990 and June 2000 (group-I) and 254 patients between July 2000 and June 2010 (group-II) demonstrating a decline of about $33 \%$. Here, $Z$ value $=2.24$ corresponds to $\mathrm{p}<0.05$ (significant). Thus the ICC has decreased significantly in group II in comparison to group I. Out of 3126 patients with attico-antral disease 627 patients developed ICC and out of 2071 patients with tubotympanic disease 6 patients developed ICC. It shows that attico-antral disease is mostly causing the ICC. A male preponderance was found in both groups. Out of 633 patients 409 was male and 224 was female whose age ranged from 5-54 years. The most common age group involved is 11-20 years with a mean age of 20.6 years. Common intracranial complications found are meningitis 256 (40\%), Brain abscess 237 (37.5\%), extracranial abscess $114(18 \%)$, followed by a few of lateral sinus thrombosis $18(3 \%)$, Subdural abscess $06(1 \%)$ and otitic hydrocephalus $02(.31 \%)$. Multiple complications were present in about 152 (24\%) of the patients. Combined intra and extracranial complication was present in $139(22 \%)$ cases. Patients having CSOM with ICC have morbidity of $16 \%$ and mortality of $17 \%$, mortality was mostly due to brain abscess. Morbidity in group II is reduced but not significantly different from that in group I. Mortality in patients with ICC in group II is 
increased to some extent but not significantly different from that in group I. Most common symptoms of patients with ICC on admission were fever, headache, hearing loss, otalgia, foul smelling discharge, vestibular symptoms and lethargy. The most observed otoscopic findings were purulent discharge/perforation in 95\%, cholesteatoma $80 \%$, granulation tissue/polyp $21 \%$.
It was also observed that poor socio-economic condition is a predisposing factor for developing ICC in CSOM. CSOM having ICC mostly comes from illiterate or under educated group of people. Bathing in ponds with swimming habits are more affected by ICC of CSOM. Village dwellers are more prone to develop ICC of CSOM.

Table-IA

Year wise frequency of Intracranial Complications of CSOM.

Group - I

\begin{tabular}{lccccc}
\hline Year & $\begin{array}{c}\text { July 90- } \\
\text { June 92 }\end{array}$ & $\begin{array}{c}\text { July 92- } \\
\text { June } 94\end{array}$ & $\begin{array}{c}\text { July 94 } \\
\text {-June96 }\end{array}$ & $\begin{array}{c}\text { July 96- } \\
\text { June98 }\end{array}$ & $\begin{array}{c}\text { July 98- } \\
\text { June 2000 }\end{array}$ \\
\hline $0-10$ & 21 & 19 & 17 & 16 & 15 \\
$11-20$ & 33 & 31 & 29 & 27 & 25 \\
$21-30$ & 16 & 15 & 14 & 13 & 12 \\
$31-40$ & 10 & 10 & 09 & 08 & 08 \\
$41-50$ & 08 & 07 & 06 & 04 & 04 \\
$>50$ & 01 & 01 & 01 & 01 & 00 \\
\hline Total & 89 & 83 & 76 & 69 & 64 \\
\hline & & & & & \\
\hline Year & July2000- & July 2002- & July 2004- & July 2006- & July 2008- \\
& June 2002 & June 2004 & June2006 & June2008 & June 2010 \\
\hline $0-10$ & 14 & 13 & 12 & 11 & 10 \\
$11-20$ & 23 & 22 & 20 & 17 & 15 \\
$21-30$ & 10 & 10 & 09 & 09 & 08 \\
$31-40$ & 10 & 08 & 06 & 04 & 02 \\
$41-50$ & 04 & 04 & 04 & 03 & 03 \\
$>50$ & 01 & 01 & 01 & 00 & 01 \\
\hline Total & 62 & 58 & 52 & 44 & 39 \\
\hline
\end{tabular}

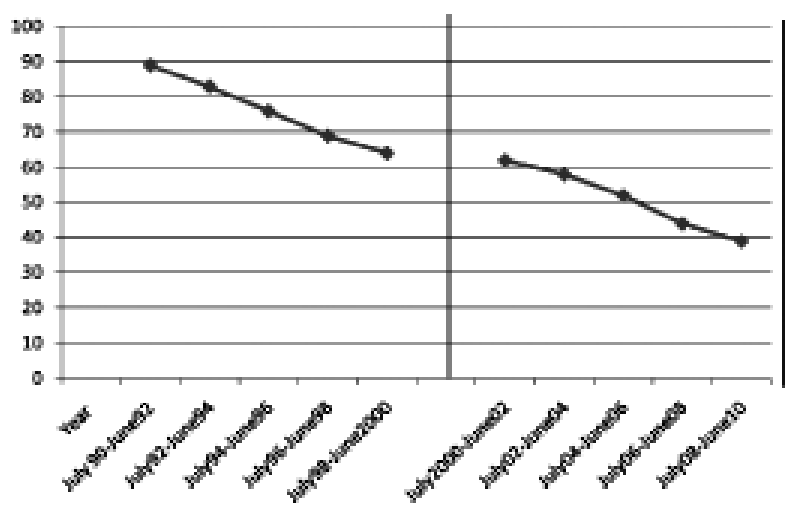

Table-IB : Year wise frequency of Intracranial Complications of CSOM
Table-II

Age wise distribution of intracranial complications (ICC) of CSOM

\begin{tabular}{lc}
\hline Age (Years) & $\begin{array}{c}\text { Total Number and } \\
\text { Percentage }\end{array}$ \\
\hline $0-10$ & $148(23.3 \%)$ \\
$11-20$ & $242(38.3 \%)$ \\
$21-30$ & $116(18.3 \%)$ \\
$31-40$ & $76(12 \%)$ \\
$41-50$ & $44(7 \%)$ \\
$>50$ & $07(1 \%)$ \\
\hline Total & $633(100 \%)$ \\
\hline
\end{tabular}


Table-III

Gender wise distribution of intracranial complications (ICC) of CSOM

\begin{tabular}{lc}
\hline Gender & Total Number and Percentage \\
\hline Male & $409(64.66 \%)$ \\
Female & $224(35.33 \%)$ \\
Total & $633(100 \%)$ \\
\hline
\end{tabular}

Table-IV

Type of CSOM causing intracranial complications (ICC)

\begin{tabular}{lccccccc}
\hline Type of CSOM & \multicolumn{3}{c}{ Group- I No. } & & \multicolumn{3}{c}{ Group II } \\
\cline { 2 - 3 } $\begin{array}{l}\text { Number and } \\
\text { percentage of CSOM }\end{array}$ & $1809(65 \%)$ & $999(35 \%)$ & 2808 & & $1317(55 \%)$ & $1072(45 \%)$ & $2389(46 \%)$ \\
ICC & 375 & 4 & 379 & & 252 & 2 & 254 \\
\hline
\end{tabular}

Table-V

Types of intracranial complications

\begin{tabular}{lccccc}
\hline Complications & Group-I & Group-II & $\begin{array}{c}\text { Total Number } \\
\text { and } \\
\text { Percentage }\end{array}$ & $\begin{array}{c}\text { Multiple } \\
\text { complication }\end{array}$ & $\begin{array}{c}\text { Intracranial } \\
\text { with } \\
\text { Extracranial }\end{array}$ \\
\hline Meningitis & 156 & 100 & $256(40 \%)$ & 40 & 31 \\
Brain Abscess & 141 & 96 & $237(37.5 \%)$ & 36 & 24 \\
(Temporal) & & & 147 & & \\
(Cerebellar) & 68 & 46 & $114(18 \%)$ & 68 & 73 \\
Extradural Abscess & 10 & 08 & $18(03 \%)$ & 06 & 09 \\
Lateral sinus thrombosis & 04 & 02 & $06(01 \%)$ & 02 & 02 \\
Subdural abscess & 00 & 02 & $02(.31 \%)$ & 00 & 00 \\
Otitic Hydrocephalus & 379 & 254 & $633(100 \%)$ & 152 & 140 \\
Total & & & & &
\end{tabular}

Table-VI

Morbidity in patients with intracranial complications (ICC)

\begin{tabular}{lccc}
\hline Morbidity & Group-I (No) & Group-II (No) & Total Number and Percentage \\
\hline Epilepsy & $12(3 \%)$ & $08(3 \%)$ & $20(3 \%)$ \\
Hemiparesis & $14(4 \%)$ & $10(3 \%)$ & $24(4 \%)$ \\
Cerebellar ataxia & $32(9 \%)$ & $22(9 \%)$ & $54(9 \%)$ \\
\hline Total & $58(16 \%)$ & $40(16 \%)$ & $98(16 \%)$ \\
\hline
\end{tabular}

Table-VII

Mortality in patients with intracranial complications (ICC)

\begin{tabular}{lccc}
\hline Morbidity & Group-I & Group-II & Total Number and Percentage \\
\hline Pre-operative & 24 & 16 & 40 \\
Post-operative & 40 & 28 & 68 \\
Total & 64 & 44 & $108(17 \%)$ \\
\hline
\end{tabular}


Table-VIII

Initial symptoms of patients with intracranial complication (ICC)

\begin{tabular}{ll}
\hline Otorrhoea & $539(85 \%)$ \\
Headache & $539(85 \%)$ \\
Fever & $439(66 \%)$ \\
Decreased hearing/Tinnitus & $358(57 \%)$ \\
Otalgia & $299(47 \%)$ \\
Vestibular symptoms (Vertigo, vomiting) & $288(45 \%)$ \\
Lethargy & $119(19 \%)$ \\
\hline
\end{tabular}

Table-IX

Otoscopic \& operation findings of patients with intracranial complication (ICC)

\begin{tabular}{lcc}
\hline Pathology & $\begin{array}{c}\text { Otoscopic findings } \\
\text { (Number and percentage) }\end{array}$ & $\begin{array}{c}\text { Operation findings } \\
\text { (Number and percentage) }\end{array}$ \\
\hline Cholesteatoma & $444(70 \%)$ & $508(80 \%)$ \\
Granulation tissue/Polyp & $126(20 \%)$ & $136(21 \%)$ \\
Both cholesteatoma and granulation tissue & $54(8.5 \%)$ & $60(9 \%)$ \\
Purulent discharge/Perforation & $570(90 \%)$ & $570(90 \%)$ \\
Eroded posterior dural/ sigmoid sinus & - & $360(57 \%)$ \\
plate/fallopian canal & & \\
\hline
\end{tabular}

\section{Discussion:}

Patients of chronic otitis media with intracranial complication (ICC) usually present very late in our country due to ignorance and lack of primary health care. Due to the improvement of socio economic condition today patients with chronic otitis media seek treatment earlier than in previous decades. Therefore the complications including the intracranial complications are decreasing day by day. At the same time intracranial complications are diagnosed earlier due to the availability of specialist service and CT scan even in the district hospital. Out of 633 patients of ICC, 627 developed due to attico-antral disease and 6 due to tubotympanic disease. It shows that atticoantral variety of disease is mostly causing the intracranial complication. Higher rates of complication in atticoantral variety are well established in other studies ${ }^{5}$. The number of patients with atticoantral disease decreased by $27 \%$ from 1809 patients in group-I to 1317 in group-II, tubotympanic disease increased by $8.4 \%$ from 999 patients in group-I to 1072 patients in group-II. Out of 5197 patients of CSOM admitted in ENT department of above mentioned hospitals between July 1990 and June 2010, 633 patients developed intracranial complication. Overall the rate of intracranial complication in the present study is $8.3 \%$. In developed countries the intracranial complications of CSOM has been greatly reduced to $0.15-0.04 \%^{8}$, due to improvement of housing, hygiene and antimicrobial chemotherapy. In a rural area of India it was found to be $4.26 \%{ }^{6}$. High incidence of intracranial complication of CSOM in our country may be due to low socioeconomic status, illiteracy, poor hygiene, overcrowding, ignorance and lack of awareness of the disease as was shown in our study also in agreement with the previous studies ${ }^{3,4,5}$. In our study, complications were more common in the age group 11-20 years which is consistent with other studies $3,7,9,10$. The reason behind this may be that this is socially the most active and health conscious age group. Besides this, the lower age incidence of the group with complications could be caused by the large number of recurrent upper respiratory infections commonly seen in this age group. Most of the patients were male. The reason for 
this is not entirely clear, but it might be possible that males may have sought medical treatment more frequently than females, as our part of the world is considered a male dominant society.

Meningitis appeared as commonest intracranial complication in some studies of Bangladesh ${ }^{3,5}$, as was also seen in our study $(40 \%)$. Patients with meningitis usually presents with fever, headache, vomiting, neck stiffness. CT scan is done to exclude multiple complications like brain abscess. Mortality rate is being reduced to $8-36 \%^{11,12,13}$. In the present study, the mortality rate from meningitis was $55 \%$, which is supported by many authors ${ }^{2,14}$. The next and most serious otogenic intracranial complications which occur commonly is brain abscess. It needs prompt diagnosis and treatment. Brain abscess was the commonest intracranial complication in other studies ${ }^{15}$. 70 patients died among 237 patients of brain abscess. Mostly died during the postoperative period, a good number of cases also died preoperatively. They were admitted into the hospital at late stage. The temporal lobe abscess is the commonest followed by cerebellar abscess ${ }^{16}$. The ratio of temporal lobe abscess \& cerebellar abscess in our study was $7: 4(2.2: 1)$. The incidence of extradural abscess in patients with intracranial complications has been reported to be 16$22 \% 17,18$. In our study, $18 \%$ patients (114) was having extradural abscess and 2 patient died with this complication. It usually present with headache and local tenderness and diagnosis made mainly during surgery. Lateral sinus thrombosis may result either from direct spread of infection from the mastoid or from thrombophlebitis of the small veins of the middle ear ${ }^{19}$. The incidence of lateral sinus thrombosis has been reported to be $19 \% 13,20$ and the mortality $10 \%{ }^{20}$. In our study, only 18 patients $(3 \%)$ were diagnosed as having lateral sinus thrombosis and mortality rate was zero. Multiple complications were present in $24 \%$ of the cases. Gupta ${ }^{21}$ reported the incidence of multiple complications being $47.82 \%$. The rate of mortality was found $14-32.6 \%$ in intracranial complications ${ }^{13,17,21}$. In our study, mortality rate was $17 \%$ (108 cases). The morbidity rate is reported to be between 11.6 and $27.9 \%{ }^{13,17}$. In the present study, morbidity was $16 \%$. Here, both morbidity and mortality were found high because the patients usually came at late stages.

In the present series, most common tympanic membrane findings were perforation of ear drum in attic (324-54\%), posterosuperior marginal $(270-45 \%)$ followed by central perforation in $6(1 \%)$ cases. These findings of perforation in eardrum was a bit higher than that of Eldestein et al. ${ }^{15}$, who found more retracted pocket than ear drum perforation. This may be due to late presentation of patients in our country due to ignorance and lack of knowledge of primary health care. Regarding duration of otorrhoea, most of the patients having intracranial complications suffered from discharge for less than 5 years, which is consistent with others ${ }^{9,12,22}$. Although logically, a longer duration of ear discharge should result in a greater chance of the development of complications, we found reverse to be true in our study. Nearly $73 \%$ of the patients had an ear discharge for less than 5 years. We have attempted to reason out the possibilities that might have led to shorter duration of ear discharge in our complicated cases. It may be that in the low socio-economic background, the suboptimal hygienic environment might have predisposed these which lead to early complications even with a shorter duration of ear discharge. Munz et al. ${ }^{18}$ reported that the most common symptoms in patients with intracranial complications were headache, nausea, vomiting, personality change and focal deficits. In our study, the most common was otorrhoea and headache then fever, hearing loss, otalgia, vestibular symptoms.

Garap and Dubey ${ }^{23}$ reported that the otoscopic findings in patients with intracranial complication (ICC) from CSOM were purulent discharge, cholesteatoma, perforation of tympanic membrane and polyp sequentially, in our study they were purulent discharge, perforation of tympanic membrane, cholesteatoma and granulation tissue/polyp. They also reported that cholesteatoma and polypoidal mucosa with granulation tissue were the most common operation findings. We 
found most commonly cholesteatoma and granulation tissue/polyp.

About educational status maximum patients had primary education (336 patients-53\%) followed by illiterate group (158-25\%). This reflects the fact that those people who are more affected have a lack of health education, are maltreated or incompletely treated by the quack or by indigenous drug. The lower socioeconomic group (404-64\%) have higher incidence of intracranial complication (ICC). It may be related to poor general health, diet and overcrowding in the home which was also found in other authors $4,5,19$.

Rural people $(75 \%)$ are much more affected than urban people $(25 \%)$ in this series. This is similar to that of Shamboul ${ }^{10}$. However, this is contradictory to that of Browning ${ }^{11}$. This contradiction can be explained by the fact that the Browning's study ${ }^{11}$ was done, where poor class people live mostly in overcrowded urban area in developed country.

\section{References:}

1. WHO. Chronic suppurative otitis media: burden of illness and management options. 2004.

2. Austin DF. Complication of acute and chronic otitis media. In: Ballenger JI, Snow JB. eds. Otolaryngology-head and neck surgery. $15^{\text {th }}$ ed. Philadelphia: Williams \& Wilkins, 1996; p. 103753.

3. Alauddin M, Chowdhury MA. Comparative study between tubotympanic and atticoantral types of chronic suppurative otitis media. Bangladesh Med Res Counc Bull 2002; 28 (1): 36-44.

4. Majed MA. ENT problem in Bangladesh. Bangladesh Med J 1979; 8: 53-8.

5. Amin ASA, Joarder MAH, Farid N, Islam MS, Ahsan MZ, Akaiduzzaman DGM. Study on complication of chronic suppurative otitis media. Northern Med J 1996; 5(1): 1-4.

6. Rupa V, Raman R. Chronic suppurative otitis media: complicated versus uncomplicated disease. Acta Otolaryngol 1991; 111: 530-5.

7. Glasscock ME, Shambough GE. Chronic suppurative otitis media. In: Surgery of the ear. $4^{\text {th }}$ ed. Philadelphia: WB Saunders; 1990; p. 249-92.

8. Kangsanarak J, Fooanat S, Ruckphaopunt K, Navacharoen N, Teotrakul S. Extracranial and intracranial complications of suppurative otitis media: report of 102 cases. J Laryngol Otol 1993; 107: 999-1004.
9. Samuel J, Fernandes CMC, Steinberg JL. Intracranial otogenic complications: a persisting problem. Laryngoscope 1986; 96: 272-8.

10. Shamboul KM. An unusual prevalence of complication of chronic suppurative otitis media in young adults. J Laryngol Otol 1992; 106: 874-7.

11. Browning GG. The unsafeness of safe ears. J Laryngol Otol 1984; 98: 23-6.

12. Fakir YA, Hanif A, Ahmed KU, Harun AA. Intracranial complication of CSOM: a study of 40 cases. Bangladesh J Otolaryngol 1999; 5(1): 11 4.

13. Palva T, Virtanen H, Makinen J. Acute and chronic mastoiditis in children. J Laryngol Otol 1985; 99: 127-36.

14. Bluestone CD. Klein JO. Otitis media with effusion, atelectasis and eustachian tube dysfunction. In: Bluestone CD, Stool SE. eds. Paediatric otolaryngology. Vol. 1. Philadelphia: WB Saunders; 1983.

15. Eldelstein DR, Parisier SC, Ahuja GS, Juarbe C, Chute $\mathrm{P}$, Wening $\mathrm{S}$, et al. Cholesteatoma in the paediatric age group. Ann Otol Rhinol Laryngol 1988; 97: 23-9.

16. Kangsanarak J, Navacharoen N, Fooanant S, Ruckphaopunt K. Intracranial complications of suppurative otitis media: 13 years' experience. Am J Otol 1995; 16(1): 104-9.

17. Ludman H. Complications of suppurative otitis media. In: Kerr AG, Booth JB. eds. Scott-Brown' Otolaryngology. Vol. 3. $6^{\text {th }}$ ed. Oxford: ButterworthHeinemann; 1996; p. 4-16.

18. Munz M, Farmer JP, Auger L, O'Gorman AM, Schloss MD. Otitis media and CNS complications. J Otolaryngol 1992; 21: 224-46.

19. Goycoolea MV, Jung TK. Complication of suppurative otitis media. In: Paperella MM. Shumrick DA, Gluckman JL, Meycrhaff WL. eds. Otolaryngology. $3^{\text {rd }}$ ed. Philadelphia: WB Saunders; 1991; p. 1381-1404.

20. Navacharoen W, Soprasuchart A. Intracranial complicatios of otitis media: a five year study. J Infect Dis Antimicrob Agents (Thai) 1984; 1: 52-7.

21. Gupta AV. A study of prevalence of complications of suppurative otitis media in rural area of Loni. Ind $\mathrm{J}$ Otol 1996; 2: 177-183.

22. Neely JG. Complications of temporal bone infection. In Cummings CW, Harker LA. eds. Otolaryngology-Head and Neck Surgery. Vol. 4. $2^{\text {nd }}$ ed. St. Louis: Mosby; 1993; p. 2840-64.

23. Garap JP, Dubey SP. Canal-down mastoidectomy experience in 81 cases. Otol Neurotol 2001; 22(4): 451-6. 